\title{
First record of notoedric mange in ocelot (Leopardus pardalis Linnaeus, 1758) in the amazon region, Brazil
}

\author{
Primeiro relato de sarna notoédrica em jaguatirica (Leopardus pardalis Linnaeus, 1758) \\ na região amazônica, Brasil
}

Alessandra Scofield ${ }^{1 *}$; Rafaelle Cunha dos Santos²; Nadino Carvalho²; Áurea Linhares Martins ${ }^{3}$; Gustavo Góes-Cavalcante ${ }^{1}$

\begin{abstract}
${ }^{1}$ Programa de Pós-graduação em Saúde Animal na Amazônia, Laboratório de Parasitologia Animal, Faculdade de Medicina Veterinária, Universidade Federal do Pará - UFPA

${ }^{2}$ Laboratório de Parasitologia Animal, Faculdade de Medicina Veterinária, Universidade Federal do Pará - UFPA

${ }^{3}$ Bioparque Amazônia Crocodilo Safari ZOO - Pará
\end{abstract}

Received February 15, 2011

Accept April 4, 2011

\begin{abstract}
This paper describes a case of notoedric mange in an ocelot (Leopardus pardalis) in the Brazilian Amazon region. A young male of approximately four months of age that was illegally kept as a pet was apprehended in Altamira, State of Pará, northern Brazil. The animal was transported to the Mangal das Garças Park in the state's capital city of Belém. The ocelot had pruritus and lesions suggestive of scabies in the head. Skin scraping material was examined under optic microscopy. There was seen a large number of eggs, larvae, nymphs and adult mites. The mean female and male sizes were $230.2 \times 200.4 \mu \mathrm{m}$ and $137.6 \times 104.9 \mu \mathrm{m}$. Based on the morphologic characteristics and morphometric analysis, this mite was classified as Notoedres cati. This is the first report of notoedric mange in L. pardalis from Brazilian Amazon.
\end{abstract}

Keywords: Notoedres cati, ocelot, Amazon, Brazil.

\section{Resumo}

O presente estudo descreve um caso de sarna notoédrica em uma jaguatirica (Leopardus pardalis) na regiáo da Amazônia Brasileira. Um macho jovem com aproximadamente quatro meses de idade, ilegalmente mantido como animal de estimação, foi apreendido em uma residência em Altamira, Estado do Pará, Brasil. O animal foi transportado para o Parque Mangal das Garças, município de Belém, estado do Pará. A jaguatirica apresentava prurido e lesóes sugestivas de escabiose na cabeça, por isso um raspado cutâneo foi realizado e examinado ao microscópio óptico. Foi observado um grande número de ovos, larvas, ninfas e ácaros adultos. Os exemplares fêmeas mediram em média $230,2 \times 200,4 \mu \mathrm{m}$, e os exemplares machos mensuraram 137,6 × 104,9 $\mu \mathrm{m}$. Com base nas características morfológicas e análises morfométricas, o ácaro foi classificado como Notoedres cati. Esse é o primeiro relato da sarna notoédrica em L. pardalis na Amazônia Brasileira.

Palavras-chave: Notoedres cati, jaguatirica, Amazônia, Brasil.

The ocelot ( $L$. pardalis) is one of eight species of neotropical felids found from southwestern Texas and western Mexico to northern Argentina and Uruguay (MURRAY; GARDNER, 1997; XIMENEZ, 1988). There are no records of this species in the highlands of Peru and Chile because it does not live at altitudes above 1200 m (MURRAY; GARDNER, 1997). In Brazil, the

\footnotetext{
*Corresponding author: Alessandra Scofield

Laboratório de Parasitologia Animal, Faculdade de Medicina Veterinária,

Programa de Pós-graduação em Saúde Animal na Amazônia,

Universidade Federal do Pará - UFPA, Rua Maximino Porpino, 1000,

Pirapora, CEP 68740-080, Castanhal, PA, Brazil;

e-mail: ascofield@ufpa.br
}

ocelot occurs in several regions, except in the southern State of Rio Grande do Sul (OLIVEIRA; CASSARO, 2005).

Following the ban on hunting and decline of international fur trade, ocelots are now losing their habitat in Brazil due to deforestation and conversion of forest areas into new areas for agriculture and cattle raising. They are now a species threatened with extinction (vulnerable category), with the exception of populations in the Amazon region (MACHADO et al., 2005).

Besides man-induced environmental changes that lead reduces the natural habitat of these animals, accidental introduction of pathogens in the wild can cause imbalance in the structure and composition of a given animal population (SIMBERLOFF, 1986; HOLMES, 1996). 
Notoedric mange is a highly contagious parasitic skin disease and is clinically manifested by intense pruritus, hyperkeratosis, peeling skin and lesions on face and ears (FRIBERG, 2006), which may extend to the limbs and other body areas of infested animals. This disease often affects domestic cats (Felis catus), wild cats and more rarely it has become a major disease among wild animals in captivity and natural reserves (VALENZUELA et al., 2000).

Notoedres spp. infestations have already been reported in animals of the orders Carnivora (PENCE et al., 1982, 1995; MAEHR et al., 1995; VALENZUELA et al., 2000; RYSERDEGIORGIS et al., 2002; NINOMIYA, OGATA, 2002; KHOSHNEGAH et al., 2007), Rodentia (LOPES et al., 1992), Chiroptera (BAKER, CRAVEN, 2003), Lagomorpha (HOPPMANN, BARROM, 2007; DARZI et al., 2007), and was also diagnosed in humans (CHAKRABARTI, 1986).

In Brazil there are few reports of notoedric mange in wild cats. This paper describes the first case of notoedric mange in an ocelot captured in the Amazon, Brazil.

A 4-month-old male ocelot (L. pardalis) cub that was illegally kept as a pet was apprehended by the Brazilian Institute of Environment and Renewable Natural Resources (IBAMA) in the city of Altamira ( $03^{\circ} 12^{\prime} 12^{\prime \prime} \mathrm{S}$ and $\left.52^{\circ} 12^{\prime} 23^{\prime \prime} \mathrm{W}\right)$, State of Pará, northern Brazil, in April 2009. The animal was transported to the Mangal das Garças Park in the state's capital city of Belém $\left(01^{\circ} 27^{\prime} 21^{\prime \prime} \mathrm{S}\right.$ and $\left.48^{\circ} 30^{\prime} 16^{\prime \prime} \mathrm{W}\right)$.

The clinical examination of the animal in quarantine showed pruritus and lesions suggestive of scabies in the head. The ocelot had clinical signs of feline notoedric mange with erythema, crusted lesions on the edges of the ears, alopecia areas around the eyes and ears, and scaly lesions in the dorsal area of the head (Figure 1a).

Skin scraping was performed with a scalpel and the specimens collected were preserved in alcohol $70 \%$, and brought to the Animal Parasitology Laboratory of Universidade Federal do Pará to search for parasites under optical microscopy. The specimens were washed with $10 \%$ potassium hydroxide, mounted on slides. The parasites were classified based on morphological and morphometric characteristics according to Bowman et al. (2001) and Uzal et al. (2007). An optical microscope (Nikon E50i) coupled to a Motic camera using Image Plus 2.0 ML software was used to measure male and female sizes. This study was approved by the Universidade Federal do Pará Committee on Animal Research and Ethics (BIO number 023-10).

The microscopic examination showed a large number of eggs, larvae, nymphs and adult mites of Astigmata order. Adult females had rounded idiosoma, legs I and II with pretarsus long pedunculated legs III and IV bristle ending in a long and anal in a dorsal position surrounded by delicate blunt spines (Figure 1b). Males had legs I, II and IV with long, pedunculated pretarsus III and leg ending in a long bristle and dorsal anus (Figure 1c). On adult specimens there were seen dorsal striae interrupted by concentric rounded scales on the central region. The mean female and male sizes were $230.2 \times 200.4 \mu \mathrm{m}$ and $137.6 \times 104.9 \mu \mathrm{m}$, respectively. Based on morphological and morphometric characteristics mites were classified as Notoedres cati. The adult mites of this species can measure 110 to $240 \mu \mathrm{m}$ (BOWMAN et al., 2001; UZAL et al., 2007).
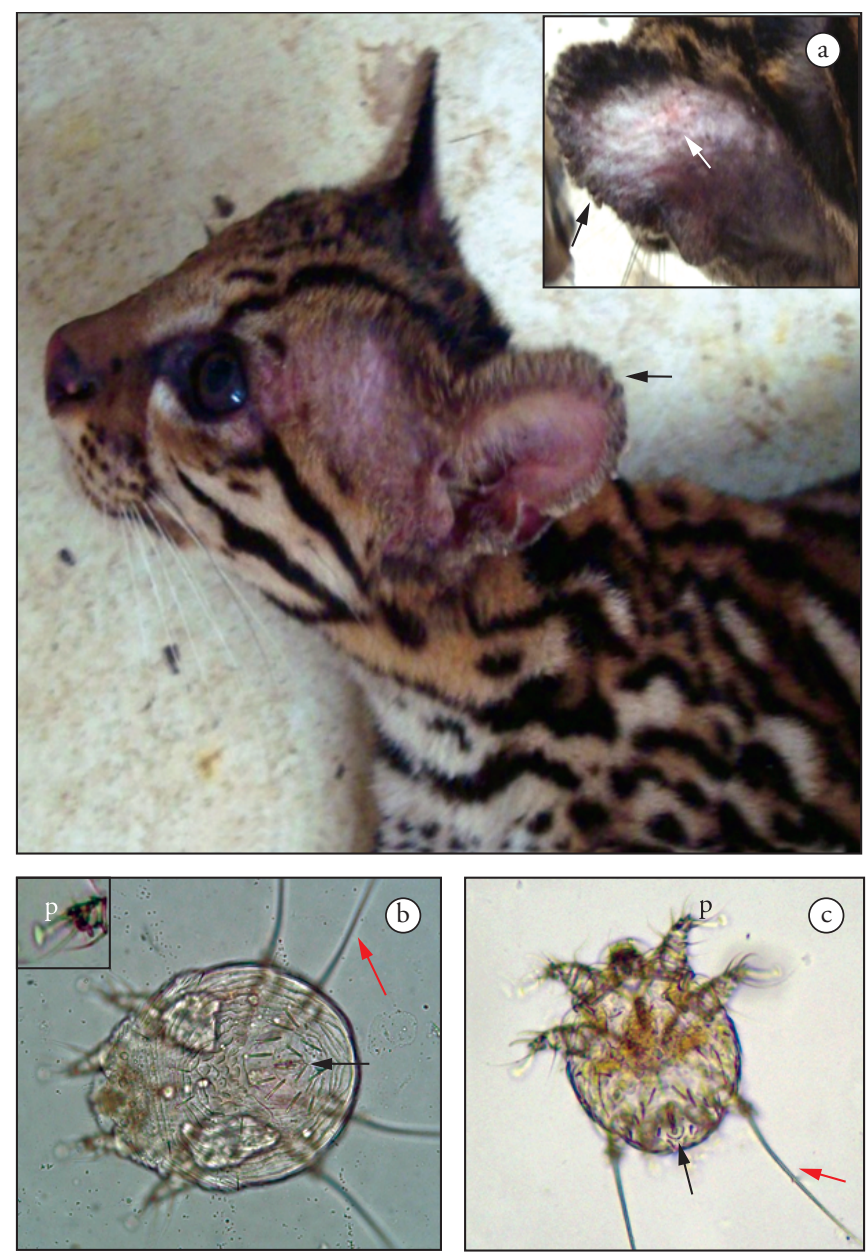

Figure 1. Notoedric mange in ocelot. a) Leopardus pardalis: scaly lesions on the edge of the ears (black arrow), erythema and alopecia areas behind the ear (white arrow) and alopecia areas around the eyes and ears. b) Notoedres cati: female with rounded idiosoma with concentric striae interrupted on the central region by rounded scales, dorsal anus (black arrow) surrounded by delicate blunt spines, legs I and II with long pedicel (p) with terminal sucker and legs III and IV ending in a long bristle (red arrow). c) Notoedres cati: male with rounded idiosoma with dorsal anus (black arrow), legs I, II and IV with long pedicel (p) with terminal sucker and leg III ending in a long bristle (red arrow).

This is the first report of notoedric mange in L. pardalis in the Brazilian Amazon. This parasitic skin disease is commonly diagnosed in domestic cats, but has not been frequently reported in wild felids. In South Africa, this disease has been reported in cheetahs (Acinonyx jubatus) (YOUNG et al., 1972) and in the United States, notoedric mange have been diagnosed in captive bobcats (Lynx rufus) (PENCE et al., 1982), Florida panther (Puma concolor coryi) (MAEHR et al., 1995), ocelot (Leopardus pardalis) (PENCE et al., 1995) and mountain lions (Puma concolor) (UZAL et al., 2007). In the Chamela-Cuixmala biosphere reserve, western Mexico, notoedric mange was diagnosed in white-nosed coatis (Nasua narica), and has been regarded as a severe animal disease in this region (VALENZUELA et al., 2000). In Switzerland, Ryser-Degiorgis et al. (2002) first reported cases 
of scabies by mixed infestations by $N$. cati and Sarcoptes scabiei in five lynx $(\operatorname{Lynx} \operatorname{lyn} x)$ found dead near the Alps. As in other countries, notoedric mange is very common in domestic cats in Brazil (ROCHA et al., 2008), but so far there was no report of this parasitic skin disease in L. pardalis in the Amazon region.

$N$. cati belongs to the Order Astigmata, Family Sarcoptidade is primarily transmitted through direct contact between infested animals (ARTHER, 2009). The ocelot apprehended by IBAMA was kept as a pet in a house among domestic cats and $N$. cati infestation was probably due to direct exposure. Similar cases of notoedric mange transmission were also reported by Valenzuela et al. (2000) in coatis in Mexico due to gregarious habits of these carnivores and Ryser-Degiorgis et al. (2002) in Switzerland where N. cati transmission was suggested between domestic cat and lynx, between red fox and lynx and among bobcats.

The clinical manifestations seen in L. pardalis were similar to those described in clinical cases of notoedric mange in domestic cats (FRIBERG, 2006), domestic dogs (KHOSHNEGAH et al., 2007) and coatis (VALENZUELA et al., 2000) including pruritus. However, rash has not been reported in $N$. cati infestations in captive wild felines as bobcat (PENCE et al., 1982).

Regarding the distribution of $N$. cati lesions in captive wild felines, Pence et al. (1982) observed extensive lesions in the head and feet of a bobcat (Lynx rufus) who died due to notoedric mange. Similar lesions were also described in an ocelot ( $L$. pardalis) found dead in Texas (PENCE et al., 1995). Maehr et al. (1995) reported alopecia, more pronounced on the dorsal surface of the head, in a female Florida panther (Puma concolor coryi) and her cub. Uzal et al. (2007) diagnosed $N$. cati infestation in two mountain lions (P. concolor) showing marked alopecia and nodules on the face, ears, shoulders, and legs. In coatis, Valenzuela et al. (2000) reported head lesions on thoracic and pelvic limbs, posterior region of the flank, and tail. In the current study skin lesions were restricted to the head of $L$. pardalis.

Factors such as capture and illegal trade of wild cats, stress, exposure to domestic species can cause serious health problems to these animals, even culminating in death and/or imbalance of the involved populations. These factors together with a reduction of these species habitat due to conversion of forest areas for agriculture and cattle raising, mainly in the Amazon, could lead to an imbalance in the population of $L$. pardalis, affecting the conservation of the species in this region of Brazil.

\section{References}

ARTHER, R. G. Mites and lice: biology and control. Veterinary Clinical Small Animal, v. 39, n. 6, p. 1159-1171, 2009. PMid:19932368. http://dx.doi.org/10.1016/j.cvsm.2009.06.009

BAKER, A. S.; CRAVEN, J. C. Checklist of the mites (Arachnida: Acari) associated with bats (Mammalia: Chiroptera) in the British Isles. Systematic \& Applied Acarology Special Publications, v. 14, p. 1-20, 2003.

BOWMAN, D. D. et al. Feline Clinical Parasitology. Iowa: Iowa State University Press, 2001. 469 p.

CHAKRABARTI, A. Human notoedric scabies from contact with cats infested with Notoedres cati. International Journal of Dermatology, v. 25, n. 10, p. 646-648, 1986. PMid:3804549. http://dx.doi. org/10.1111/j.1365-4362.1986.tb04527.x

DARZI, M. M. et al. Clinico-pathological, histochemical and therapeutic studies on concurrent sarcoptic and notoedric acariosis in rabbits (Oryctolagus cuniculus). Veterinarski Arhiv, v. 77, n. 2, p. 167-175, 2007.

FRIBERG, C. Feline facial dermatoses. Veterinary Clinical Small Animal, v. 36, n. 1, p. 115-140, 2006. PMid:16364780. http://dx.doi. org/10.1016/j.cvsm.2005.09.002

HOLMES, J. C. Parasites as threats to biodiversity in shrinking ecosystems. Biodiversity and Conservation, v. 5, n. 8, p. 975-983, 1996. http://dx.doi.org/10.1007/BF00054415

HOPPMANN, E.; BARRON, H. W. Ferret and rabbit dermatology. Journal of Exotic Pet Medicine, v. 16, n. 4, p. 225-237, 2007. http://dx.doi.org/10.1053/j.jepm.2007.10.002

KHOSHNEGAH, J. et al. A case report of notoedric mange infestation in a 3-month-old pointer. Iranian Journal of Veterinary Research, v. 8, n. 2, p. 184-185, 2007.

LOPES, C. M. L. et al. Skin lesions on Rattus rattus alexandrinus caused by Notoedres sp. (Acari). Memórias do Instituto Oswaldo Cruz, v. 87, n. 2, p. 313-314, 1992. http://dx.doi.org/10.1590/S007402761992000200025

MACHADO, A. B. M.; MARTINS, C. S.; DRUMMOND, G. M. Lista da Fauna Brasileira Ameaçada de Extinçáo: Incluindo a Lista das Espécies Quase Ameaçadas e Deficientes em Dados. Belo Horizonte: Fundação Biodiversitas, 2005. 157 p.

MAEHR, D. S. et al. Notoedric mange in the Florida Panther (Felis concolor coryi). Journal of Wildlife Diseases, v. 31, n. 2, p. 251-254, 1995.

MURRAY, J. L.; GARDNER, G. L. Leopardus pardalis. Mammalian Species, n. 548, p. 1-10, 1997. http://dx.doi.org/10.2307/3504082

NINOMIYA, H.; OGATA, M. Notoedric mange in two freeranging North American racoons (Procyon lotor) in Japan. Veterinary Dermatology, v. 13, n. 2, p. 119-121, 2002. PMid:11972895. http://dx.doi.org/10.1046/j.1365-3164.2002.00284.x

OLIVEIRA, T. G.; CASSARO, K. Guia de campo dos felinos do Brasil. São Paulo: Instituto Pró-Carnívoros, Fundaçáo Parque Zoológico de São Paulo, Sociedade de Zoológicos do Brasil, Pró-Vida Brasil, 2005. 80 p.

PENCE, D. B.; MATTHEWS, F. D.; WINDBERG, L. A. Notoedric mange in the Bobcat, Felis rufus, from South Texas. Journal of Wildlife Diseases, v. 18, n. 1, p. 47-50, 1982. PMid:7097869.

PENCE, D. B. et al. Notoedric mange in an Ocelot (Felis pardalis) from Southern Texas. Journal of Wildlife Diseases, v. 31, n. 4, p. 558-561, 1995. PMid:8592392.

ROCHA, G. S. et al. Freqüência de ácaros em cães e gatos no município de Mossoró, Rio Grande do Norte, Brasil. Acta Scientiae Veterinariae, v. 36, n. 3, p. 263-266, 2008.

RYSER-DEGIORGIS, M. P. et al. Notoedric and sarcoptic mange in free-ranging Lynx from Switzerland. Journal of Wildlife Diseases, v. 38, n. 1, p. 228-232, 2002. PMid:11838224.

SIMBERLOFF, D. The proximate causes of extinction. In RAUP, D. M.; JABLONSKI, D. Patterns and processes in the history of life. Berlim: Springer-Verlag, 1986. p. 259-276. 
UZAL, F. A. et al. Notoedric Mange in Two free-ranging Mountain Lions (Puma concolor). Journal of Wildlife Diseases, v. 43, n. 2, p. 274-278, 2007. PMid:17495313.

VALENZUELA, D.; CEBALLOS, G.; GARCÍA, A. Mange Epizootic in White-nosed Coatis in Western Mexico. Journal of Wildlife Diseases, v. 36, n. 1, p. 56-63, 2000. PMid:10682744.
YOUNG, E.; ZUMPT, F.; WHYTE, I. J. Notoedres cati (Hering, 1838) infestation of the cheetah: Preliminary report. Journal of the South African Veterinary Association, v. 43, n. 2, p. 205, 1972. PMid:4680377.

XIMENEZ, A. Notas sobre felideos neotropicales, IX Felis (pardalis) mitis F. Cuvier, 1820 en el Uruguay (Mammalia: Carnívora: Felidae). Comunicaciones Zoológicas del Museo de Historia Natural de Montevideo, v. 12, n. 168, p. 1-7, 1988. 